\title{
Brownfields revitalization: it's all about choices
}

\author{
S. O’Malley
}

Director of Economic Development, City of Derby,

Vice Chairman, Regional Brownfields Partnership,

Chairman, Comprehensive Economic Development Strategy for the

Lower Naugatuck Valley of Connecticut, USA

\begin{abstract}
It can be said of New England and specifically the towns and cities that make up the Lower Naugatuck Valley ("the Valley") that these communities have almost made a complete circle back to the rivers and sites along those rivers that once created and supported great wealth and thriving communities. The towns and cities that have seen decline in employment, lack of developable land and a reduction in population have experienced regression, in part, because of the decline in manufacturing jobs, the difficulties faced with redeveloping contaminated properties, and the enormous task of restoring the rivers and parcels of land along those rivers to usable sites for economic growth and prosperity.

When addressing brownfields issues, most municipalities face a steep learning curve. Part of the educational process is looking back on the history of these sites and understanding the role they played in forming thriving communities and the potential role they play today in economic development. How does a municipality, once again, realize potential and capitalize on the very sites that spurred economic growth in the $19^{\text {th }}$ and early $20^{\text {th }}$ centuries in the United States? To realize the benefits of revitalizing these areas, economic developers and municipal officials need to focus on the factors that contributed to past successes and appreciate how economies were driven by the factories and mills that dotted the Lower Naugatuck Valley in order to realize the benefits of revitalizing these areas. Taxpayers need to understand the critical role these industries played (and can play) in helping to increase the tax base. Allowing these sites to remain fallow will further contribute to the problems already facing these communities. Municipal officials need to feel comfortable in spending taxpayer dollars on sites that, at first glance, seem to offer little hope. Successful buy in from the elected officials leads to successful buy in from the community and, more often than not, will result in a very positive outcome. The charge for the professionals is to raise money, build partnerships, find skilled technicians and learn the basics of the environmental assessment process. We will explore methods of reviving brownfield sites through a summary of available direct and indirect funding options and creative solutions for municipalities. It is important to understand that the revitalization and restoration of these sites is cyclical and essential to the resurgence of a community's economic growth and prosperity.

Keywords: funding sources, redevelopment, creativity.
\end{abstract}




\section{Rivers: the lifeblood of the valley}

The early settlers had both beauty and utility in mind when they settled in the Valley. The six communities that make up the Valley today are Ansonia, Derby, Oxford, Beacon Falls, Seymour and Shelton. Surrounded on three sides by gently rolling hills, the Valley is a place where businesses and industries thrived. Earning its reputation as an industry-rich area where the economy of towns and cities pivoted around several copper, brass, and rubber factories, heavymachinery manufacturers, and metalworking plants. The smokestacks that jut up into the sky along the Housatonic and Naugatuck Rivers were a sign of the Valley's successful economy.

In the 1600s water power was essential for commerce and for industry. Derby, in particular was the hub at which the two largest rivers in the Lower Valley met. To the northwest was the 160 mile long Housatonic River, which leads up into western Massachusetts, and to the northeast is the Naugatuck River, which flows for 40 miles into the interior of Connecticut. The two rivers converge in Derby and cut a wide swath for 13 miles down to the Long Island Sound.

In the 1800 s waterpower was used from the rivers for manufacturing and industrial communities that developed along the Naugatuck and Housatonic Rivers. Attracted by abundant waterpower, industrialists quickly built factories and the Lower Valley joined what was considered to be the Industrial Revolution. Between 1836 and 1891 businesses grew to accommodate industry and their growing number of employees. Communities that grew up along the rivers were designed to support industrial, commercial and residential buildings. Ansonia and Derby, in particular, were devoted primarily to the manufacturing of rolls and heavy machinery for five major industries, rubber, plastics, metals, cane sugar and paper. Factories grew at an almost geometric rate along the rivers. During the Industrial Age in America, every town or city that had water power to turn a factory wheel became a manufacturing community and their products were used for sale to foreign markets.

\section{The remnants of the industrial age}

The Lower Valley received the most serious insult from the commercial operations; the contamination/pollution of our rivers and waterways due to the disposal of industrial waste. By the late 1800s, smaller iron, brass, steel and copper factories that were prevalent throughout the Valley, gave way to larger, mass produced enterprises. The Lenox Glass Works (along the Housatonic River) was the largest factory in the world under one roof.

"Today, what is left of the big building is a flattened and filled foundation beside the railroad and the river..... What remains of its machinery is sometimes grotesquely visible in the river, where it was jettisoned. " Smith [1]

Shortly thereafter, heavy industries that clung to the riverbanks where they originally obtained water power were dying out. In the Years after World War II, manufacturing employment declined nearly $9 \%$ in the Valley. Unemployment in 
the Valley rose well above $10 \%$ and remained that way, standing at $17 \%$ in the early 1980s.

The Valley continues to struggle with the after-effects of the early industrial activities as evidenced by the numerous, abandoned and underutilized sites along these waterways. Most communities in Connecticut and especially those in the Valley are small and every acre is of considerable economic value. The lack of space forces communities to focus attention on revitalization efforts. Economic development professionals in older urban areas struggle to rebuild their tax base with limited space. Abandoned or underused industrial and commercial facilities can provide additional space and an avenue towards a higher tax base if the obstacles involved in reusing abandoned sites can be overcome.

\section{Rise from the rubble}

The decline of the industrial age and the decline of manufacturing in New England led to an exodus of large manufacturers who created and then ultimately left environmental problems in their wake.

Robert LeFevre, a local historian wrote 'There are only two sources from which all the difficulties we face arise. There are difficulties caused by nature and there are difficulties caused by man' (Cawley et al [2]). The only sure way to eliminate the difficulties caused by man is for municipalities to begin to understand what got us to this point and to understand the choices available to reverse the contamination and redevelop these once prosperous and desirable locations.

\subsection{How to navigate the solutions for redevelopment}

The difficulties facing communities with multiple brownfields sites involve complex solutions and the fix often requires a demonstrated and well orchestrated commitment of public and private resources. It is critical that municipal developers understand federal, state and local support can provide a good portion of the necessary resources for cleanup funding. Just as the waterways defined, early on, our role in the economic climate, these waterways can also be potential sources of funding for the abandoned sites that were built up around them. According to a study done by the U.S. Housing and Urban Development (HUD) agency, the number one obstacle to redevelopment of brownfield sites are the cleanup costs (including assessment, remediation, and legal expenses) and their relationship to the total project costs. This dominates all other factors as an investment deterrent.

\subsection{Where is the money?}

For smaller communities, the sources of funding are as numerous as the problems created by brownfields. In 1994, the U. S. Environmental Protection Agency (EPA) made its first three federal grants with a pilot program called the Brownfields Economic Redevelopment Initiative designed to return idle or underused industrial and commercial facilities back to productive use, in 
situations where redevelopment had been complicated by potential environmental contamination. The brownfields program was intended to make old industrial sites more attractive to new industrial users and to overcome the reluctance of prospective developers to move in because of the fear of incurring future environmental liability, i.e., "buying into a problem." EPA's initial pilot was successful in that it motivated communities and developers to restore the sites, incorporating the efforts of lenders, regulators, and others. The cyclical revitalization of the sites along the river ways could once again begin to create jobs, improve the local economy, generate more tax income and stimulate property values.

In the Valley's older manufacturing towns and cities, most economic development effort centers on these abandoned sites, thereby creating the need for multiple alternative funding sources. Funding sources must be as abundant and diverse as the communities that are in need of assistance. In order to realize beneficial redevelopment of a brownfields site, municipalities and communities must realize the endless possibilities for direct and indirect assistance.

Support for EPA's efforts and the brownfields concept comes from a wide array of states and localities, environmental groups, business, developers, and community activists. Communities have the potential to leverage federal, state, and private funds to improve the environment by addressing low-level, low-risk contamination that might otherwise lay dormant. The brownfields program was established administratively EPA under the aegis of the Superfund program. Superfund is the federal government's principal program for cleaning up the nation's contaminated waste sites and protecting health and the environment from releases of hazardous substances. Since the inception of EPA's pilot program, the program has expanded to include brownfields assessment grants, revolving loan fund grants to help finance the actual cleanups, job training grants, technical and financial assistance from approximately 20 participating federal agencies Since EPA's initial program, many federal agencies have followed suit including, the U.S. Department of Defense, U.S. Health and Human Services, U.S. Small Business Administration, U.S. Department of Commerce, U.S. Department of Transportation, Economic Development Administration, U.S. Department of Education and coordination with state, local and non-governmental efforts.

Most states provide incentives for participating in voluntary cleanups through some form of liability release or third-party liability protection. Other incentives include a streamlined process, financial or tax incentives, and technical assistance. Voluntary clean up programs do not typically focus on redevelopment and they don't specifically target urban sites, however, they help get simple less contaminated sites remediated regardless of whether they are reused. Brownfields programs focus on redevelopment and can be part of a broader State or municipal strategy aimed at improving urban areas. The State of Connecticut has also demonstrated its commitment to the revitalization of brownfields by creating a task force that has improved and updated the state's brownfields legislation, creating increased flexibility, mirroring the innocent landowner legislation of the federal government and creating an Office of Brownfields 
Remediation consisting of the Connecticut Department of Environmental Protection, Connecticut Development Authority, and the Connecticut Department of Economic and Community Development. Connecticut and other States use voluntary cleanup grants to capitalize a revolving loan fund, or to develop a risk sharing pool, an indemnity pool, or insurance mechanism for providing financing for response actions.

\section{Downtown redevelopment in the valley: a variety of choices}

At the end of an industrial era that once defined the Valley, every town and city along the Naugatuck and Housatonic Rivers is looking to recreate its downtown. The Valley's downtowns consists of older, abandoned, industrial buildings requiring environmental assessment money to determine the level and extent of contamination before any movement can be made.

In the case of the City of Shelton, situated on the Housatonic River with a population of approximately 40,000, a well-known developer leveraged private funds to acquire a former asphalt plant. The site acquisition and work associated with its environmental cleanup and demolition is roughly estimated at $\$ 6.6$ million. This will make room for the creation of energy efficient green buildings that serve as upscale condominiums. This new population of condominium owners has generated new economic growth. Additionally, the City of Shelton was able to receive federal assistance from the U.S. Economic Development Administration (EDA) due to sudden and significant job loss, which then spurred on job growth in other areas of the City that had been abandoned due to contamination and the migration outward of a large company. The City rebuilt a portion of its downtown, creating a greenway and farmer's market, which in turn generated additional activity.

Beacon Falls, a small town on the Naugatuck River, was able to take a Transportation and Community Systems Preservation Program (TCSP) grant from the U.S. Department of Transportation and create a gateway into their downtown area. They have attracted visitors and have transformed a once desolate and contaminated area into a recreational area. A portion of Beacon Falls redevelopment funds were used to continue a walkway along the Naugatuck River that will attract more pedestrians to its commercial district on Main Street. Funding for Beacon Fall's river walk came from EPA and the Connecticut Department of Environmental Protection.

The City of Waterbury, the $5^{\text {th }}$ largest City in Connecticut, located along utilized U.S. Department of Defense brownfield funding to clean up an abandoned military facility once used to make ammunition for the war efforts and transformed the site into a generous mall that has helped increase the grand list, employ hundreds and helped to alleviate the burden of high property taxes.

The City of Ansonia, located adjacent to Derby and the Naugatuck River received U.S. Federal Emergency Management Agency Funds to revitalize a contaminated site that had burned down. In Ansonia's downtown there is a brand new Target store, which generates hundreds of thousands of dollars in tax revenue for the City annually on the site of this former mattress manufacturing building. 
The City of Derby will restore its downtown with transportation money from the U.S. Department of Transportation and the State Department of Transportation for two major road projects in the region. One of these projects (a portion of Route 34) is located on Main Street in Derby and is adjacent to the City's downtown redevelopment area. Connecting streets can be enhanced with additional street grid funding can be sought through discretionary money from the U.S. Department of Transportation, dovetailing on the major road improvement projects. Enhancements to this road make the downtown extremely desirable to the thousands of cars and trucks that pass by daily. The City will use its Small Cities money from the U.S. Department of Housing and Urban Development and the Connecticut Department of Economic and Community Development for façade improvements to the local businesses in the downtown area - some of the buildings are old and dilapidated and this money will help generate interest and attract customers, U.S. Economic Development Administration (EDA) funds will be used to open up access to a vacant lot owned by the City and create an industrial park near the downtown area, Clean Water funds will be used to repair and replace aging infrastructure and add new sewer and water lines and state urban act funds will be used to help knock down blighted buildings. Additionally, the City of Derby has a tax district. Special tax districts are created to resuscitate blighted areas, freeze the amount of propertytax money going to local governments and divert any new money to local redevelopment projects. The City of Derby also has an Enterprise Corridor Zone that provides additional tax incentives to the developers in the downtown area. Derby is also looking to clean up and create open space in a contaminated area that will serve as open space and a new boat dock that will attract new residential development. All of these creative ideas will help to recreate a thriving new downtown for Derby.

Once the level of contamination and the extent of contamination are determined and the proposed reuse decided upon, then a plan must be established to create a funding mechanism to help redevelop the site. Ideally, most cities and towns would like their downtowns to be thriving mixed use centers that draw people from all over. Depending on the plan for redevelopment, multiple funding sources exist and often there are numerous opportunities for creative uses of those funds. Many sites require major infrastructure improvements that will need a number of private, federal and state options. Utility costs in these sites can be reduced by working cooperatively with the local gas and electric companies to help defray the initial development expenses. Energy efficient projects and "green" buildings are additional sources of money saving techniques. Enterprise Zones and Enterprise Corridors established through the State of Connecticut offer tax rebates and abatements helping defer cost of development and serving as additional incentives. In many cases, road improvements must be made to accommodate increased traffic in sites where redevelopment is taking place. These road improvements will most likely be funded through State, federal and municipal programs and can be designed in such a way as to make economic development more affordable because it improves visibility, increases parking and makes improvements to existing property along the roadways. A community 
can also incorporate some of its pre-existing enhancements to complement brownfields redevelopment. A greenway, for example, draws visitors into the downtown area and increases awareness of a City's or Town's attractive characteristics.

\section{Conclusions}

\subsection{New options on the horizon}

New ways to address brownfields are continually being developed. For example, EDA will make brownfield sites eligible for certain grants and will establish a demonstration program for "brightfield sites" which are defined as brownfields redeveloped using solar technologies.

In addition to state, city and community representatives, EPA has developed cooperative relationships with other federal agencies and created the Interagency Working Group on Brownfields, with staff from more than 20 federal agencies and the Interagency Steering Committee to share knowledge on economic redevelopment, environmental principals, and to develop a comprehensive, coordinated federal approach to local communities. With EPA's efforts leading the way and other agencies following suit on both the federal and state levels, the possibilities for redevelopment are endless. There is renewed hope and interest in these once great manufacturing sites. There is cooperation, problem solving, and creative solutions that are returning these sites to productive reuse.

In short, there are many options available to municipal developers, including, but not limited to tax incentives, utility incentives and reductions depending on the size of the project, lead abatement funding, energy efficiency programs, and various other incentives and programs. These tools are available to assist the many cities and towns that are dealing with the economic stresses associated with living in post industrial communities, including aging infrastructure, failing bridges and roadways, high unemployment rates, crowded schools, blight and crime. It takes commitment, creativity and a desire to reinvent your community.

\section{References}

[1] Smith, Chard Powers, The Housatonic River, Rinehart \& Company: New York, N.Y., p.366, 1946.

[2] Cawley, James and Margaret, Exploring the Housatonic River and Valley, A.S. Barnes, South Brunswick, N.J. p. 43, 1978. 